\title{
Komunikasi Sosial Program Pembangunan Masyarakat Dalam Perspektif Terkini
}

\author{
Susan Daniel \\ Program Studi Pendidikan Luar Sekolah, Fakultas Keguruan dan Ilmu \\ Pendidikan, Universitas Palangka Raya, Indonesia \\ email: susan.daniel@fkip.upr.ac.id
}

Diterima: 26-09-2021; Diperbaiki:01-10-2021; Disetujui:02-10-2021

\begin{abstract}
ABSTRAK
Pembangunan merupakan proses tidak hanya mencakup peningkatan fisik dan material saja, melainkan pula merupakan perubahan sosial yang menuntut didalamnya pemerataan sosial bersifat partisipatori secara luas untuk memajukan keadaan sosial dan kebendaan termasuk keadilan yang lebih besar, kebebasan, dan kualitas yang dinilai tinggi melalui perolehan kontrol yang lebih besar terhadap lingkungan. Oleh karena itu, salah satu pembahasan dalam artikel ini adalah model komunikasi pembangunan. Proses pembangunan melibatkan pengoperasian komunikasi untuk keberlangsungannya. Gerak pembangunan mengarahkan sub-sub sistem di dalam entitas pembangunan bergerak searah dengan tujuan pembangunan tersebut. Salah satu sub sistemnya adalah komunikasi dan informasi. Komunikasi pembangunan mengalami dinamika yang berproses dan mengarah kepada wujud yang lebih interaktif serta partisipasif.
\end{abstract}

Kata kunci: Perspektif, Komunikasi, Pembangunan

\section{PENDAHULUAN}

Pendapatan perkapita tidak hanya dijadikan patokan utama dalam mengukur pertumbuhan ekonomi saat ini. Standar yang dipakai oleh pemerintahan terdahulu untuk mengukur keberhasilan pembangunan. Konsep pembangunan dengan memakai standar keberhasilan pembangunan dari tabungan bersih (nett saving) dan investasi tinggi yang dimungkinkan karena pendapatan perkapita anggota individu masyarakat yang tinggi tersebut menyisakan masalah pada lowongan pekerjaan, distribusi pendapatan dan penghapusan kemiskinan secara mendasar. Hal ini dapat diasumsikan, jika ketiga faktor itu mengalami penurunan, maka sangat sulit untuk menilai itu semua merupakan hasil dari pembangunan, meskipun pendapatan perkapita naik berlipat.

Pembangunan secara sederhana bisa diartikan sebagai usaha yang dilakukan oleh masyarakat untuk meningkatkan taraf hidup mereka. Peningkatan taraf hidup bagi Seers (1969) merupakan upaya pembangkitan dari kemiskinan dan ketidak adilan. Ini terlihat dari definisinya mengenai pembangunan yang berarti upaya membangkitkan masyarakat dari kemiskinan, tingkat melek huruf yang rendah, pengangguran dan ketidakadilan sosial.

Pembangunan, kata Scott Cambell (1996), seorang Profesor di Michigan University, adalah menjaga keseimbangan sebuah segi tiga, agar titik beratnya tetap di tengah. Ada tiga sudut segi tiga dimana satu tudungnya bertengger pertumbuhan ekonomi. Di tudung berikutnya adalah kelestarian alam dan pada tudung yang terakhir adalah keadilan sosial. Membangun berarti mengelola tiga macam 
kepentingan tersebut yang selalu tarik menarik dan tolak-menolak dalam perebutan prioritasnya masing-masing.

Cambell menyebutkan bahwa yang di tengah segitiga, yang diharapkan sebagai titik berat yang menyeimbangkan semua, adalah (sustainable development). Artinya, suatu pembangunan yang sekaligus menguntungkan, hijau dan Adil. Konflik kesejahteraan, ekologis dan keadilan dalam gerak pembangunan diakui sebagai sesuatu yang abadi dan berlaku global, tidak mengenal waktu dan tempat. Karena itu, tidak boleh dihindari atau ditutupi tapi harus dibuka guna mendorong prakarsa kreatif dan kolektif menuju pembangunan yang berkelanjutan dan berkeadilan.

Everett M. Rogers (1985) menyatakan bahwa, secara sederhana pembangunan adalah perubahan yang berguna menuju suatu sistem sosial dan ekonomi yang diputuskan sebagai kehendak dari suatu bangsa. Pada bagian lain Rogers menyatakan bahwa komunikasi merupakan dasar dari perubahan sosial.

Lebih tajam lagi Roger (1979) memandang pembangunan sebagai suatu bentuk perubahan sosial yang dinyatakannya dengan mendefinisikannya sebagai proses perubahan sosial yang bersifat partisipatori secara luas untuk memajukan keadaan sosial dan kebendaan termasuk keadilan yang lebih besar, kebebasan, dan kualitas yang dinilai tinggi melalui perolehan mereka akan kontrol yang lebih besar terhadap lingkungan.

Jelas sekali bahwa pembangunan hendaknya tidak diartikan semata untuk peningkatan kehidupan materi saja melainkan non materi pula, agar dapat mencerminkan keseluruhan aspek kehidupan termasuk aspek non materi. Aspek non materi pembangunan berbentuk proses perolehan pengetahuan, informasi, dan keterampilan-keterampilan baru.

\section{PEMBAHASAN}

\section{Komunikasi sebuah Proses Perubahan}

Sebagai suatu proses, pembangunan harus dilihat sebagai suatu pembelajaran. Pembelajaran untuk peningkatan kemampuan masyarakat baik secara individu maupun kolektif, dengan tidak hanya menyesuaikan diri terhadap perubahan tetapi juga mengarahkan perubahan untuk tujuan yang dikehendaki.

Kebutuhan belajar membutuhkan upaya-upaya tersediri akibat dari proses pembangunan yang multidimensi baik hal itu berkaitan dengan pengaruh sains dan teknologi, masuknya kebudayaan dan nilai-nilai asing ke dalam masyarakatmasyarakat tradisional, maupun perubahan-perubahan konteks nasional dan internasional sebagai wadah pembangunan.

Komunikasi merupakan bagian integral dari pembangunan sebuah masyarakat, Karena pembangunan bertujuan membangun manusia seutuhnya membutuhkan proses yang melibatkan pengoperasian komunikasi untuk keberlangsungannya. Gerak pembangunan mengarahkan sub-sub sistem di dalam entitas pembangunan bergerak searah dengan tujuan pembangunan tersebut. Salah 
satu sub sistemnya adalah komunikasi dan informasi

Perubahan yang dikehendaki dalam pembangunan tentunya perubahan ke arah yang lebih baik atau lebih maju dari keadaan sebelumnya. Oleh karena itu peranan komunikasi dalam pembangunan harus dikaitkan dengan arah perubahan tersebut. Artinya kegiatan komunikasi harus mampu mengantisipasi gerak pembangunan. Agar terarah dengan baik ke arah sasarannnya, diperlukan rencana tersusun rapi dan sistematik dan bersifat stratejik untuk mengembangkan komunikasi dan informasi.

Komunikasi tetap dianggap sebagai perpanjangan tangan para perencana pemerintah, dan fungsi utamanya adalah untuk mendapatkan dukungan masyarakat dan partisipasi mereka dalam pelaksanaan rencana-rencana pembangunan. Setiap pembangunan dalam suatu bangsa memegang peranan penting. Oleh karena itu, pemerintah dalam melancarkan komunikasinya perlu memperhatikan strategi apa yang dapat digunakan untuk menyampaikan pesan sehingga efek yang diharapkan itu sesuai dengan harapan.

\section{Model Komunikasi Pembangunan}

Strategi pada hakekatnya adalah perencanaan (planning) dan manajemen untuk mencapai suatu tujuan. Tetapi untuk mencapai tujuan tersebut, strategi tidak berfungsi sebagai peta jalan yang menunjukkan arah saja, melainkan harus menunjukkan bagaimana taktik operasionalnya. Dengan demikian strategi komunikasi merupakan paduan dari perencanaan komunikasi (communication management) untuk mencapai suatu tujuan. Untuk mencapai tujuan tersebut strategi komunikasi harus dapat menunjukkan bagaimana operasionalnya secara taktis harus dilakukan, dalam arti bahwa pendekatan (approach) bisa berbeda tergantung pada situasi dan kondisi.

Pembangunan melibatkan berbagai komponen di dalamnya termasuk media massa sebagai salah satu unsur komunikasi dan informasi yang memiliki tugas pokok perubahan sosial sebagaimana dinyatakan oleh Wilbur Schramm, yaitu (1) menyampaikan kepada masyarakat informasi tentang pembangunan nasional agar mereka memusatkan perhatian pada kebutuhan akan perubahan, kesempatan dan cara mengadakan perubahan, sarana-sarana perubahan, dan membangkitkan aspirasi nasional, (2) memberikan kesempatan masyarakat untuk mengambil keputusan, memperluas dialog agar melibatkan semua pihak yang akan membuat keputusan mengenai perubahan, memberikan kesempatan kepada para pemimpin masyarakat untuk memimpin dan mendengarakan pendapat rakyat kecil dan menciptakan arus informasi yang lancar dari bawah ke atas, (3) mendidik tenaga kerja yang diperlukan pembangunan dari anak- anak sampai orang dewasa, dari keterampilan baca tulis sampai keterampilan teknis yang langsung diterapkan. Tugas pokok ini menimbulkan fungsi-fungsi media massa yakni sebagai pemberi informasi, pembuatan keputusan dan pendidik.

Media massa bersinergi dengan komponen lainnya dalam pembangunan 
untuk mencapai tujuan bersama. Strategi yang tepat dalam pengimplementasian tujuan pembangunan adalah dengan mengadopsi strategi baru dalam proses komunikasi antar manusia yakni salah satunya adalah pendekatan konvergensi yang didasarkan pada model komunikasi yang sirkular dan lebih manusiawi menggantikan model linear yang umum dianut selama ini.

Pendekatan konvergensi berarti berusaha menuju suatu pengertian yang lebih bersifat timbal balik di antara partisipan komunikasi dalam hal pengertian, perhatian, kebutuhan ataupun titik pandang. Selain itu ditingkatkan pula partisipasi semua pihak yang ikut serta dalam proses komunikasi demi tercapainya suatu fokus bersama dalam memandang permasalahan yang dihadapi. Dengan kata lain, pendekatan ini bertitik tolak dari dialog antar semua pihak dan bukan hanya ditentukan oleh salah satu pihak saja.

Strategi komunikasi dengan pendekatan konvergensi menjadi model paten bagi pengembangan komunikasi di Indonesia bernuansa terkini jika dikontraskan dengan model sebelumnya. Model komunikasi sebelumnya berkembang dalam pembangunan masyarakat dianggap dominan dan dianut oleh sistem pembangunan Indonesia berorientasi pada pentahapan pembangunan yang diharapkan berproses menuju tahap tinggal landas (take off).

Menurut model itu individu memainkan peran utama dalam pentahapan atau disebut modernisasi tersebut. Individu berperan sebagai pembuat keputusan dan sekaligus sebagai partisipan. Acuan utama dalam model ini adalah modernisasi ditranformasi dari nilai- nilai orang barat yang dianggap memiliki ciri-ciri individu yang berorientasi kemajuan tinggi. Pemikiran ini memunculkan ideologi pembangunan dijabarkan sebagai bentuk "tetesan ke bawah". Arus informasi mengalir satu arah dari pengirim ke penerima negara barat yang dianggap sebagai sumber atau pusat dan negara berkembang sebagai daerah. Sedangkan pada tinjauan internal wilayah negara, informasi mengalir dari pusat atau ibukota menuju ke daerah. Model ini pada pengejawantahannya mengalami kendala pada partisipasi berbentuk umpan balik yang dinilai kurang memadai.

\section{KESIMPULAN}

Proses komunikasi pembangunan memerlukan suatu model komunikasi yang baik. Proses pembangunan melibatkan pengoperasian komunikasi untuk keberlangsungannya. Gerak pembangunan mengarahkan sub-sub sistem di dalam entitas pembangunan bergerak searah dengan tujuan pembangunan tersebut. Salah satu sub sistemnya adalah komunikasi dan informasi. Komunikasi pembangunan mengalami dinamika yang berproses dan mengarah kepada wujud yang lebih interaktif serta partisipasif.

\section{DAFTAR PUSTAKA}

Achmad, A.S.. 1990. Manusia dan Informasi. Makassar: Hasanuddin University Press. 
Ardianto, Elvinaro. 2005. Komunikasi Massa: Sebuah Pengantar. Bandung: Simbiosa Rekatama Media.

Griffin, Em. 1991. A First Look at Communication Theory. New York: McGrawHill Inc.

Jahi, Amri dkk. 1988. Komunikasi Massa dan Pembangunan Pedesaan, di NegaraNegara Dunia Ketiga: Suatu Pengantar. Jakarta: PT. Gramedia

Littlejohn, Stephen W. 1996. Theories Of Human Communication. California: Wadsworth Company Publishing.

Wiryanto. 2000. Teori Komunikasi Massa. Jakarta: PT Grasindo

Garcia,M.B. 1985. Sosiology of Development: perspektive and issues. Philippines: National Book Store, Inc. Hanson, A

Waskita, Djaka. 2005. Komunikiasi pembangunan untu pemberdayaan. Jurnal Organisasi dan Manajemen, volume 1 nomor 1, September.

Yossita wisman. 2017. Komunikasi effektive dalam dunia pendidikan. Jurnal Universitas Merdeka Malang, 1-9 website internet. 